\title{
Reengineering Business Process Manufacturing Company Sales Module Using Odoo V12.0 Application
}

\author{
Ni Wayan Rika Hari W ${ }^{a 1}$, I Made Sukarsa ${ }^{a 2}$, Dewa Made Sri Arsa ${ }^{a 3}$ \\ ${ }^{a}$ Information Technology Study Program, Faculty of Engineering, Udayana University \\ Bukit Jimbaran, Bali, Indonesia Phone. (0361) 701806 \\ e-mail: ${ }^{1}$ haririka77@gmail.com, ${ }^{2}$ sukarsa@unud.ac.id, ${ }^{3}$ dewamsa@unud.ac.id
}

\begin{abstract}
Abstrak
Industri manufaktur menerapkan penggunaan Enterprise Resource Planning untuk menjalankan bisnis proses perusahaan, membangun komunikasi yang baik dan meningkatkan kualitas pelayanan. Penelitian bertujuan untuk memberikan usulan bisnis proses reengineering pada departemen sales menggunakan aplikasi Odoo V12.0 agar sistem dapat terintegrasi. Metodologi yang digunakan pada penelitian ini yaitu Bisnis Proses Reengineering, dimana penelitian hanya berfokus pada bidang sales saja. Bisnis proses yang sedang berjalan di perusahaan yaitu pembelian produk, sales order dan invoice secara manual. Reengineering yang telah dilakukan yaitu proses penjualan produk, proses sales order, dan proses pembayaran. Reengineering sudah dapat terlaksana cukup baik dengan menggunakan metode User Acceptance Test dan mendapatkan tanggapan setuju sebagai nilai terbesar pada setiap aspek. Hasil yang diperoleh berdasarkan 5 kategori yaitu item konten sebesar 63\%, item modul sebesar $53 \%$, item elemen multimedia sebesar $88 \%$, aspek navigasi sebesar $70 \%$ dan item kegunaan sebesar $82 \%$.
\end{abstract}

Kata Kunci: Business Process Reengineering, Enterprise Resource Planning, Odoo V12.0, Sales, User Acceptance Test

Abstract
The manufacturing industry applies the use of ERP to run corporate business processes, build good communication and improve service quality. This study aims to provide a Business Process Reengineering proposal to the sales department using the Odoo V12.0 so that the system can be integrated. The methodology used in this research is Business Process Reengineering, where the research only focuses on the sales field. Existing business processes, namely purchasing products, sales orders and invoicing manuall. Reengineering that has been carried out is the product sales process, the sales order process, and the payment process. Reengineering has been carried out quite well by using the User Acceptance Test method and obtaining agreed responses as the greatest value in every aspect. The results obtained are based on 5 categories, namely content items by $63 \%$, module items by $53 \%$, multimedia element items by $88 \%$, navigation aspects by $70 \%$ and usability items by $82 \%$.

Keywords: Business Process Reengineering, Enterprise Resource Planning, Odoo V12.0, Sales, User Acceptance Test

1.

Introduction

Most companies have used information system in managing management and improving the quality of the company. Information system is an interaction that is used to support people's activities with the use of information technology [1]. The sales process is an activity that requires the use of an information system because it is very helpful and has an important role in processing customer data, invoicing, and data, so that it can carry out the sales process [2]. The sales department will deal directly with the warehouse and the production department to find out the availability of the number of goods. Based on this, an integrated information system is needed to help the company's business processes.[3] 
Enterprise Resourse Planning is an integrated system that can help corporate business processes [4]. ERP has a part in the form of Manufacturing Resource Planning which is widely used in manufacturing companies in carrying out company management such as business aspects, business strategy planning and conducting production planning based on resource requirement [5]. One of the companies in the manufacturing industry, for example PT. $\mathrm{XYZ}$, is a company engaged in the Chicken Slaughterhouse. This company has several departments such as sales, warehouse, production and others. [6]Each department has their respective duties such as the sales department to manage product sales, product offerings and create sales reports. Based on the results of interviews that have been conducted with department heads, the sales department has several problems, such as the storage of sales data and customer data is still managed manually so that the information received is not 'real time'.[7]

Previous research that became a reference in this study was Business Process Reengneering with the Application of Open Source in the Sales and Procurement Process, which was done by Riya Widayanti and Adrian in 2018. This study discusses companies that have difficulty accessing information in the decision-making process and solutions given by researchers, such as conducting Business Process Reengineering using the Odoo application implementation method to improve the company's business processes [8].

Based on the ongoing business processes, a business process proposal is needed, namely Business Process Reengineering to optimize business activities and improve customer service [9]. Reengineering is done by using the Odoo V12.0 application specifically for the sales department only. Odoo is an integrated information system and has been widely used by many countries, with various features to support company performance [10].

\section{Research Method}

This research was conducted based on several stages, namely literature study, problem identification, data processing, data analysis, and system testing. The method used in the Business Process Reengineering research application is the ERP system, namely Odoo V12.0.

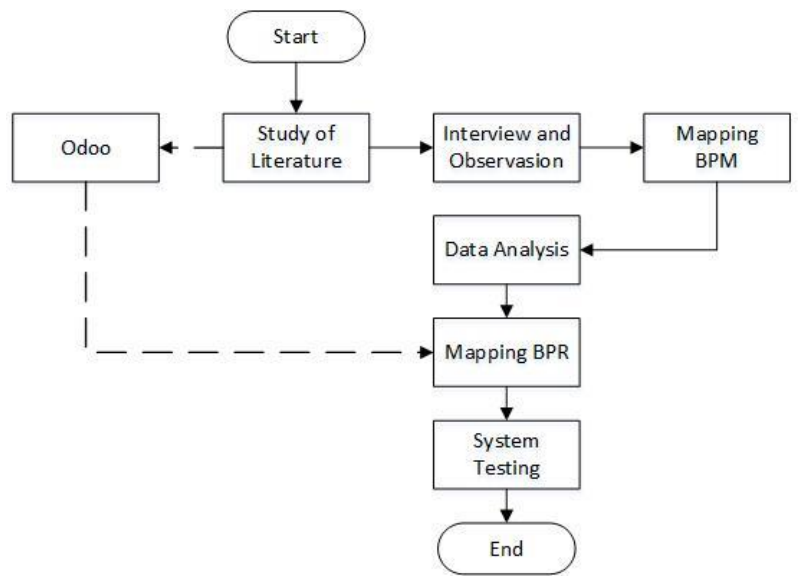

Figure 1. Research Method

\subsection{Literature Study}

The literature study stage was carried out by collecting information related to theory and method to support research. The process is carried out after collecti'ng theories and methods, namely analyzing the Odoo application, the process that occurs in the application so that it can produce a reengineering process for the company. Literature studies are obtained based on related books and journals.

\subsection{Identifying Problem}

The stage of problem identification is carried out in two ways, namely interviews and field observations. Interviews were conducted by conducting questions and answers to company managers in the areas of sales, warehouse and production in order to fulfill research 
needs. Field observation is carried out in the form of observing the business processes that are running at the company, such as observation on the production process of broilers.

\subsection{Data Processing}

The stages of data processing can be carried out after obtaining the information and data needed in the study from the results of conducting interviews and field observations. The data obtained is then identified in order to know the business processes that occur in the sales field. So that data processing can provide an overview of the business processes that are currently running at the company.

\subsection{Data Analysis}

The data analysis stage is carried out by analyzing the current business processes of the company so that they can be adjusted to the new business processes using the Odoo application. The results obtained at the data analysis stage can be used as a new business process proposal to the company.

\subsection{System Testing}

System testing is done by conducting a demo application to the company, where the company will assess the performance of the Odoo reengineering business process. The system will be tested based on company data and company business processes which will be adjusted to the business process system. The evaluation method used is by using a questionnaire based on predetermined aspects. The questionnaire given consisted of several questions that had been compiled related to the system display, the system's module functions, the proposed reengineering business process, and usage management.

\section{Literature Study}

The ideas and concepts in this research come from literature reviews in the form of articles, scientific journals, research reports, books and internet sites that become references in this research.

\subsection{Information System}

Information systems is a field that combines computer science with business and management. Information systems can run if they consist of technology or tools, the media used, organized procedures, and human resources that make up an organized system. a combination of technology and humans, namely to support operations and management. The purpose of using information systems is to help make decisions and produce the desired information. Information systems are always associated with the use of technology used in everyday life for both individual and organizational needs.

\subsection{Marketing and Sales}

Marketing is an activity within a company to determine a strategy for introducing products to customers. The strategy designed aims to attract customer interest in a product or service based on the information provided. Marketing is the main key in the company because it will determine the processes in other divisions. So that marketing has a very important role in the success of the company itself. Sales are all activities selling products or services to customers. A good sale is how sales can approach customers in a good way.

\subsection{Enterprise Resource Planning (ERP)}

Enterprise Resource Planning is an integrated information system that functions to manage business processes in an organization. ERP systems can integrate every department in the company so as to provide easy access to the information needed. The use of ERP software that is equipped with hardware can support integration and be able to coordinate every data in each department so that business processes can run. The implementation plan that is built includes planning, analysis, design, implementation and technical support. The implementation that has been carried out on the ERP system in the company needs to be evaluated through the user side so that it can be compared with existing systems. The impact of implementing an ERP system is expected to have a positive impact on company performance. 


\subsection{Manufacturing Resource Planning (MRP II)}

Manufacturing Resource Planning is an effective planning method of all the resources of a manufacturing company [11]. MRP II consists of various interconnected functions such as business planning, operations and sales planning, production planning, determining the main schedule, material planning requirements, capacity planning requirements, and implementing support systems for materials and capacities. The results of this system are integrated with financial reports such as business planning, purchase commitment reports, delivery budgets, and inventory projections in rupiah. Strategic business planning integrates marketing, financial, and production plans and activities to create plans that are intended to achieve overall company goals.

\subsection{Business Process Reenginering}

Business Process Reengineering is a radical and dramatic business process process so that the business process becomes more effective and efficient without the organizational structure and function of the business process itself. The purpose of this process is to integrate the company's activities into one process at the same time so that it is more efficient and effective in processing. Making improvements to the current business process is very important to do because the company is always faced with competition from other companies. This happens because customers continually ask for goods and services that are in better condition and can be obtained easily and quickly.

\subsection{User Acceptance Testing}

User Acceptance Testing is a method of testing a system to find out which users can accept the system [12]. The test itself is adjusted to user needs, where the data used is related to the user and the system workflow. The purpose of testing with this method is to evaluate the system performance of an organization carried out by the development team. The UAT method is also very effective in knowing the failure of a system. The measurement scale in the questionnaire uses a Likert scale, which is indicated for the scoring of the questions given. The scores related to responses are Strongly Disagree $(T S)=1$, Disagree $(K S)=2$, Quite Agree $(C S)=3$, Agree $(S)=4$ and Strongly Agree $(S S)=5[13]$.

\subsection{Odoo V12.0}

Odoo is an open source ERP system and provides various types of modules that can be tailored to suit all company needs [14]. Odoo consists of 2 categories, namely the community scale and the enterprise scale. Community scale is a system that can be used free of charge, but the limitations it has are that the available modules cannot be used as a whole. Enterprise scale is a paid system but can use all existing modules. Odoo is an integrated system so that every available module can be related to each other. Odoo has been used by many companies, both small and large scale companies. Odoo can also be applied to various sectors, such as the trade, textile, agriculture sector, and others. This difference illustrates Odoo's very high level of flexibility so that it can reach all types of existing companies.

\section{Result and Discussion}

The results of this study contain discussions related to the research that has been carried out. This section consists of the ongoing sales business process, business process reengineering, Odoo implementation and the results of the tests that have been carried out.

\subsection{Company Sales Process}

The business process that occurs in the sales module is a sales process that starts from ordering products by customers to the payment process. The interconnected departments include customer, sales, accounting and warehouse. The existing business processes in the sales module can be seen as follows. 


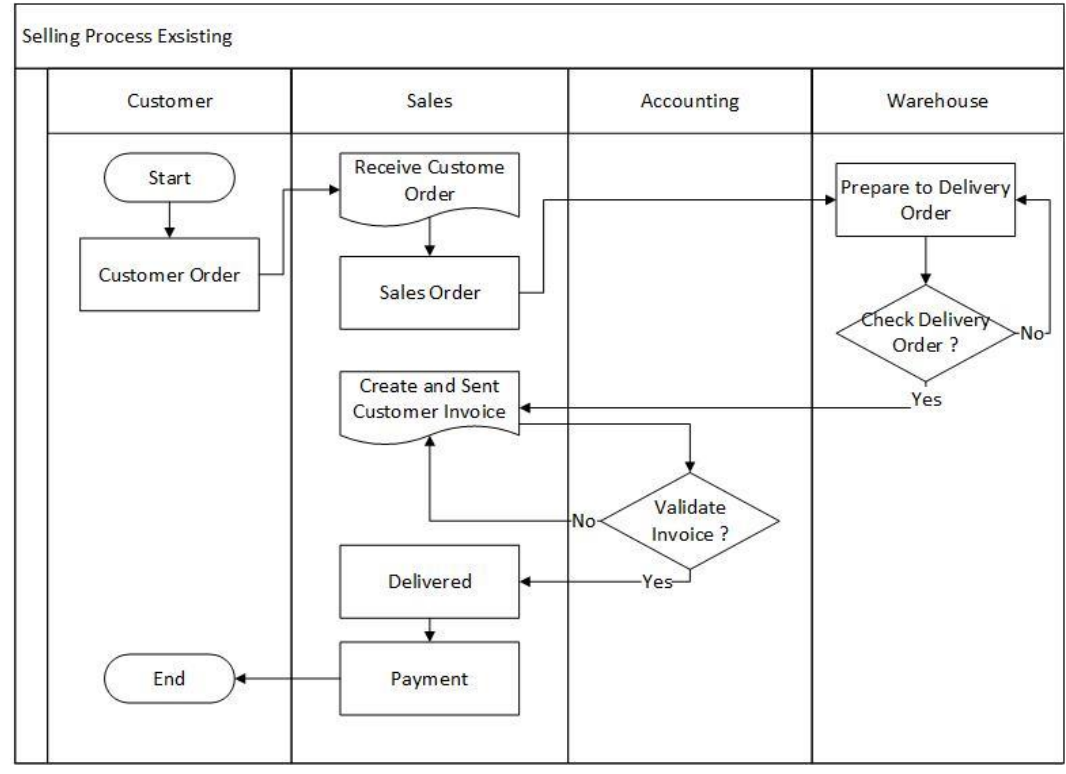

Figure 2. Company Sales Process

\subsection{Reengineering Business Process}

Business process reengineering carried out in the sales module is the addition of the company's business processes which are adjusted to the Odoo application business process. There are 3 types of business process reengineering, namely the addition of a product offering process, a sales order process, and a payment process.

\subsubsection{Product Offering Process}

The addition of the product offering process is done online, namely through the company email and will be sent to the customer's email. This process only applies to customers who already have a cooperation contract with the company, while customers who do not have a cooperation contract can make the purchase process directly to the sales department. The product offer or what is called a quotation that has been received by the customer, and then the customer who is interested in the offer can confirm it by signing it online, while the customer who is not interested can reject the offer. Based on the observations that have been made in the sales process business of PT. XYZ, there is a difference between the existing business processes and reengineering, these differences can be seen as follows.

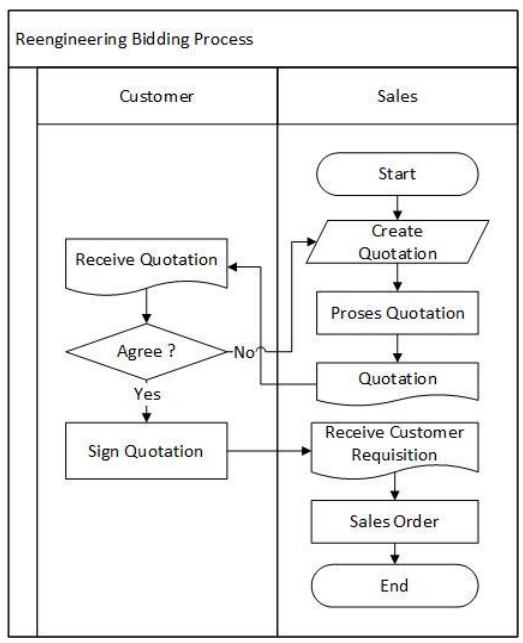

Figure 3. Product Offering Process Comparison 
The sales process that is currently running in the company receives customer orders which are then immediately processed by the sales department. Meanwhile, the reengineering sales process adds product offering features to customers or customer quotations that contain the type of product and the price offered and can also provide information related to promotions on certain products.

\subsubsection{Sales Order Process}

The sales order process that is currently running in the company undergoes reengineering after being adjusted to the Odoo application business process. According to the observations that have been made, there is a difference between the existing sales order process and the sales order reengineering process. The following is the difference between the existing sales order process and the sales order reengineering process of PT. XYZ.

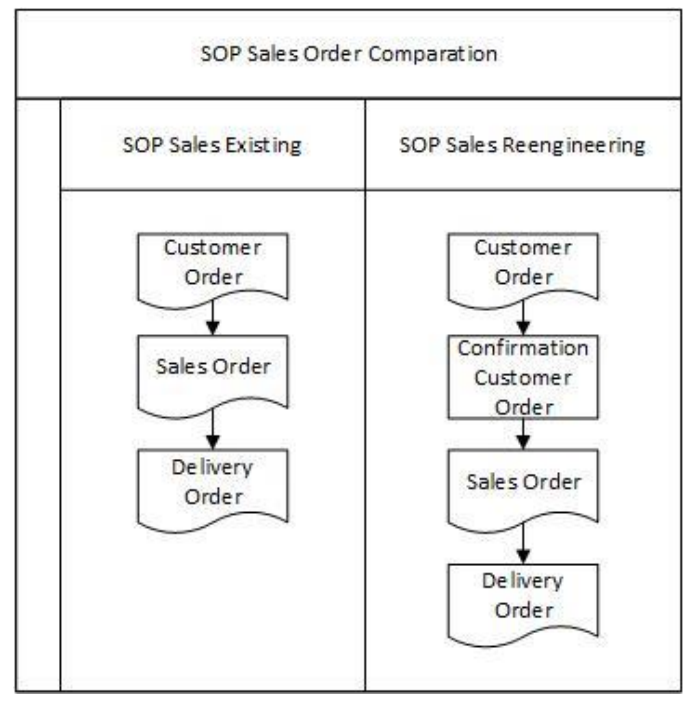

Picture 4. Sales Order Process Comparison

The sales order process that is currently running in the company is still done manually. The sales department and the warehouse department are also not automatically connected to each other. Meanwhile, in the business, the sales order reengineering process will connect the sales and warehouse departments automatically because of the integrated nature of the system. There is also an additional process, namely confirmation of customer orders in the sales department as validation of orders made by customers.

\subsubsection{Payment Process}

The payment process at the company can be done in cash or non-cash. Customer invoice is given during the delivery process. Meanwhile, in the reengineering process carried out by the Odoo application, customer invoices can be sent to customers via email. Based on the results of the research that has been done, there are differences between the ongoing payment process and the business reengineering payment process, which are as follows. 


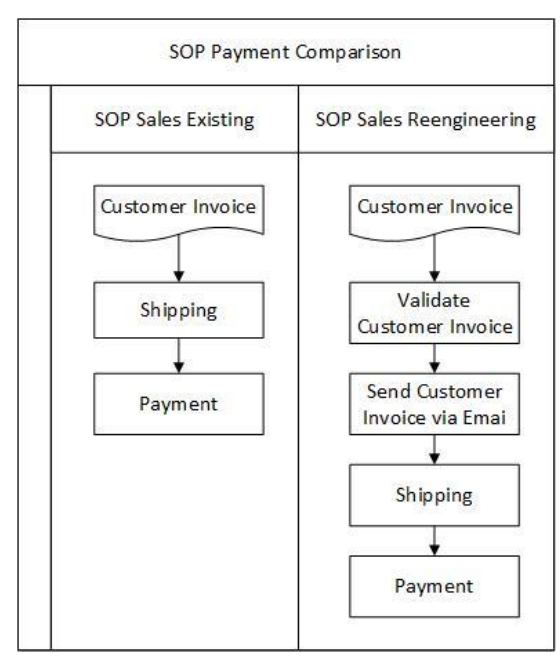

Figure 5. Payment Process Comparison

The payment process at the company can be done in cash or non-cash. Customer invoice is given during the delivery process. Meanwhile, in the reengineering process carried out by the Odoo application, customer invoices can be sent to customers via email. Based on the results of the research that has been done, there are differences between the ongoing payment process and the business reengineering payment process, which are as follows.

\subsection{Odoo Implementation}

Implementation of Odoo application for the company PT. XYZ, which are by managing customer data (customer database), sales quotation and sales orders, customer invoices and payments and sales reports.

\subsubsection{Customer Database}

Customer database provides information from customers who have made purchase transactions to the company. The function of customer data is that the company can find out the purchase transactions that have been made. Related customer data can be in the form of name, address, telephone number, email address and so on.

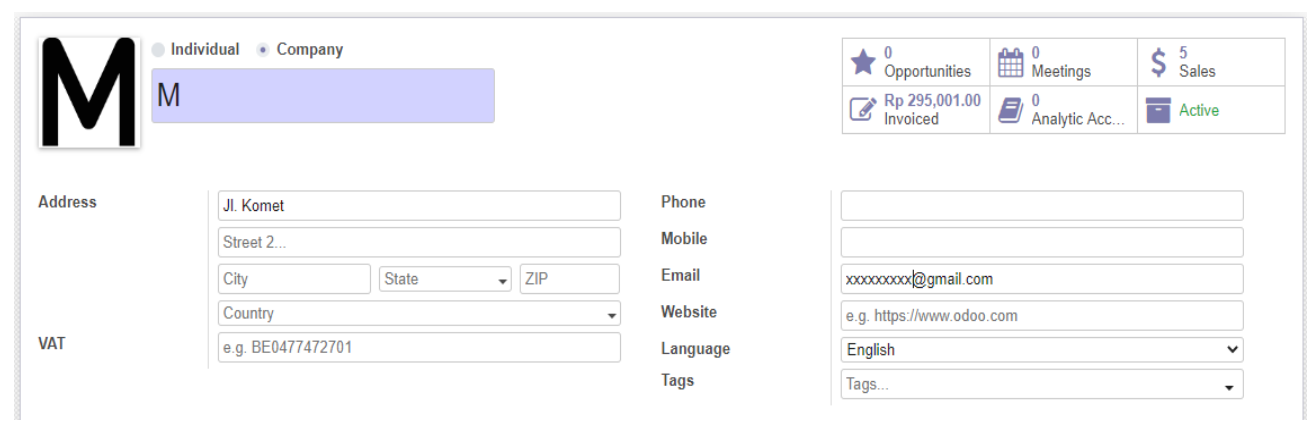

Figure 6. Customer Database

Figure 6 is a display of customer data that has been inputted into the Odoo application, where the data entered is in the form of name, address and others. Besides being able to view customer information, this page can also be used to view the activities depicted on the board which is given a red box. As for customer activities in the form of many purchases and payments that have been made, and can manage meeting schedules with customers. 


\subsubsection{Sales Quotation and Sales Order}

Sales Quotation is an offer document provided to customers. Bid documents provide offers related to products that the company provides to customers. The completed bid document can then be sent via email to the customer.

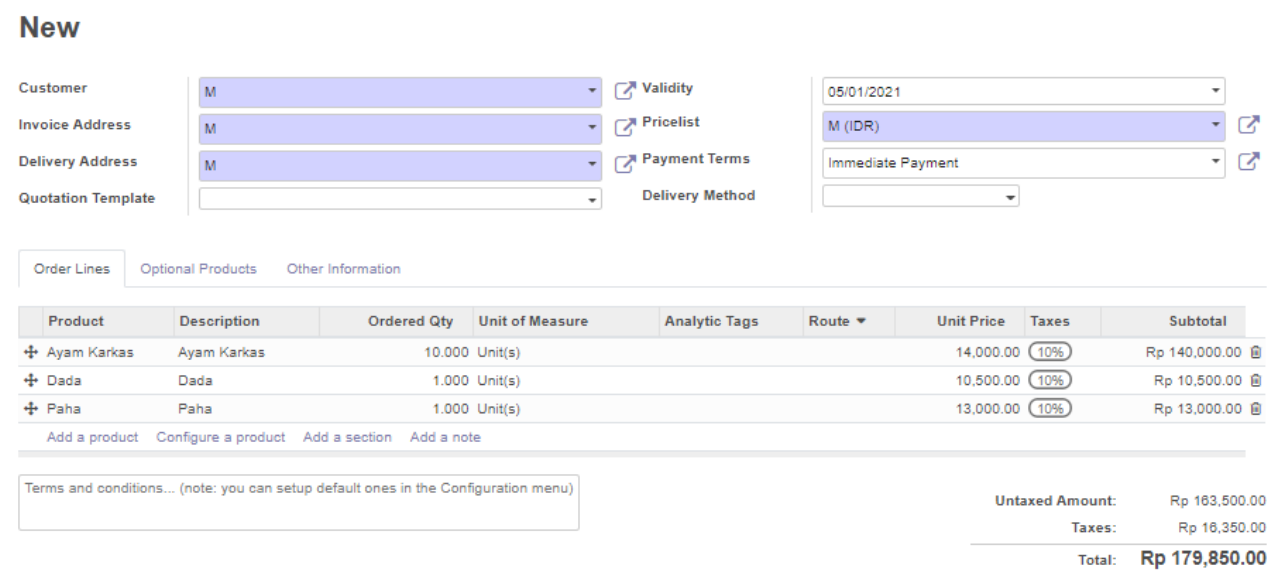

Figure 7. Sales Quotation

Making a quotation begins by inputting the name of the customer and information related to the destination address, billing address, type of payment, type of delivery, type of product, number of products and price offered. Quotations that are ready then can be sent via email. Customers who have received the quotation can confirm, where the confirmation is made in the form of an online signature. The confirmed quotation will then be received by the sales so that it can be processed into a sales order.

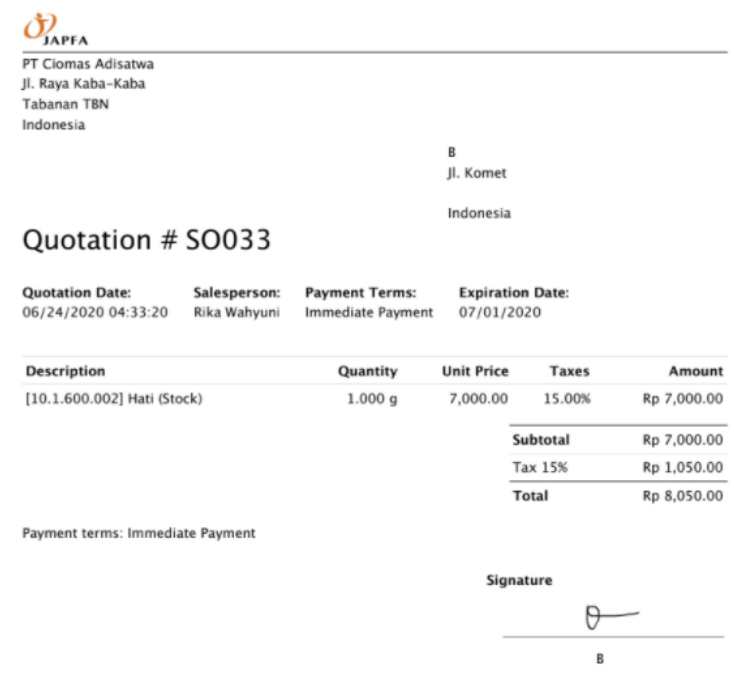

Figure 8. Sales Order Document

The sales order document is a list of purchases made by the customer, the sales order document here has been adjusted to the offer document that has been confirmed by the customer. After going through the sales order process, then enter the payment process.

\subsubsection{Customer Invoice and Payment}

Customer invoice is making payment invoice to customer. Invoice creation will be carried out by the sales module while validation will be carried out by the invoicing module. 


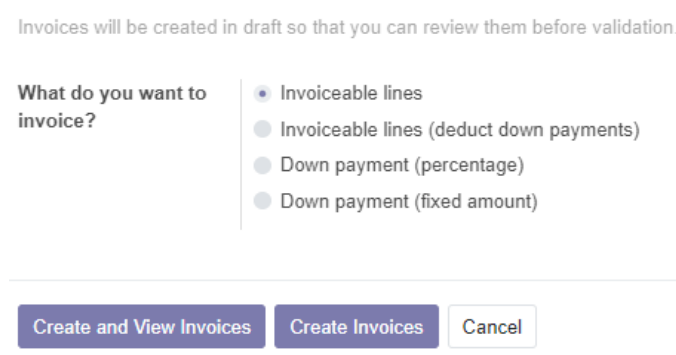

Figure 9. Invoice Order

Making invoices is continued by selecting the type of invoice specified, there are four types of invoices, namely invoiceable line (payment in full), invoiceable line / deduct down payment (payment of the remaining bill), down payment percentage (paying down payment in percentage) and fixed amount (payment based on deal).

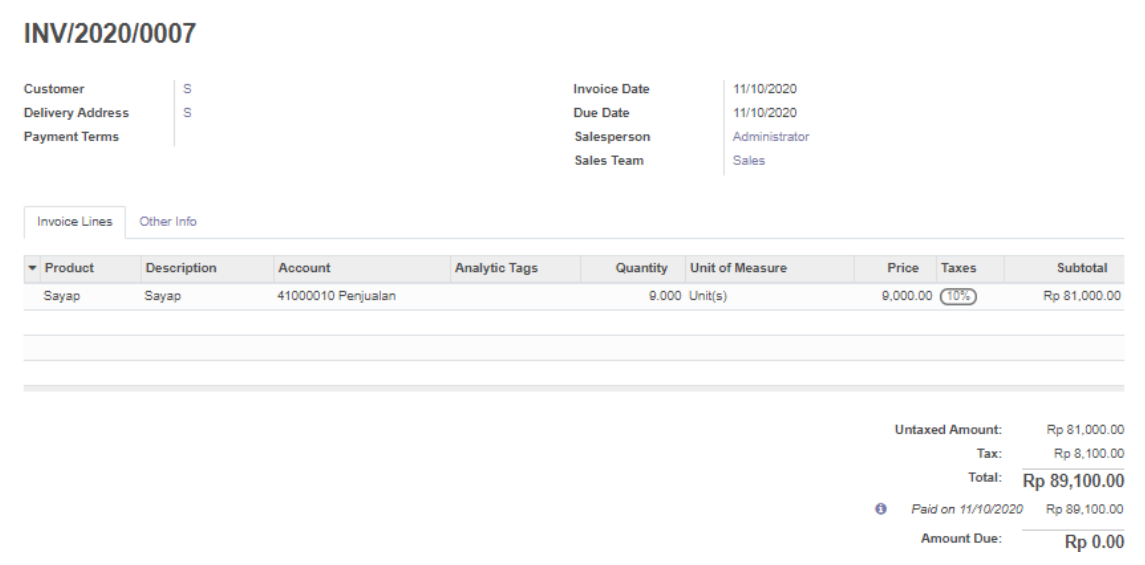

Figure 10. Payment Invoice

The payment process can be done after validating the invoice. Payment methods can be made via bank or cash. Invoices that have been paid, the invoice status becomes paid, so the sales transaction can be said to be successful.

\subsubsection{Sales Report}

Sales report is the result of a report from the sales process that has been carried out, while the sales report can be seen from the total revenue, total opinion based on customers and can find out what types of products are most in demand.

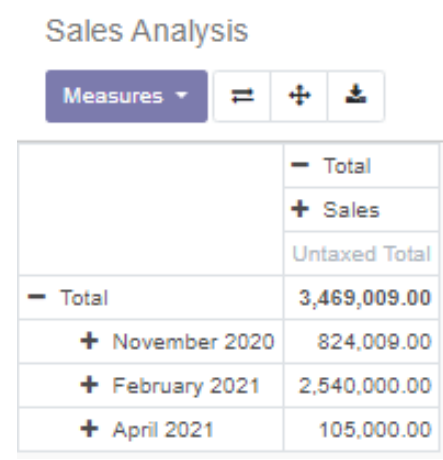

Figure 11. Sales Report 
Sales reports are illustrated by customer name, product name and time of day. In terms of time, three categories can be described, namely daily, monthly and annual sales reports. Everything can be determined according to the search filter according to the available groups, making it easier to find sales results in different categories. Report views can be described with pivots (tables) and graphs such as bar charts, line charts and pie charts.

\subsection{Test Result}

Tests carried out at the company PT. XYZ, namely through a questionnaire to measure the feasibility of the system. The testing process begins with a system demo with the company and distributing questionnaires. The test was conducted by involving 10 respondents consisting of employees from the sales department. The questionnaire consisted of 5 assessment items consisting of 22 questions. Testing is done using the UAT (User Acceptace Testing) method and the Linkert scale. The Linkert scale consists of 5 options, namely Strongly Disagree, Disagree, Quite Agree, Agree and Strongly Agree.

Table 1. Result of Questionnaire

\begin{tabular}{cccccc}
\hline \multirow{3}{*}{ Item } & \multicolumn{4}{c}{ Frequency } \\
\cline { 2 - 6 } & 1 & 2 & 3 & 4 & 5 \\
\cline { 2 - 5 } & $\begin{array}{c}\text { Strongly } \\
\text { Dissagree }\end{array}$ & Dissagree & $\begin{array}{c}\text { Quite } \\
\text { Agree }\end{array}$ & Agree & $\begin{array}{c}\text { Strongly } \\
\text { Agree }\end{array}$ \\
\hline Content Item & & $3 \%$ & $28 \%$ & $68 \%$ & $8 \%$ \\
Module Item & & & $48 \%$ & $53 \%$ & \\
Multimedia & & $12 \%$ & $88 \%$ & \\
Element Item & & & & \\
Navigation & & & $28 \%$ & $70 \%$ & $3 \%$ \\
Aspect & & $18 \%$ & $82 \%$ & \\
Useful Item & & & & \\
\hline
\end{tabular}

The analysis was carried out on the results of the questionnaire which was divided into 5 items. The first content item is an assessment of the type of information displayed on the application. The largest percentage of content items is with Agree responses of $63 \%$ and the smallest percentage with Disagree responses of $3 \%$. The two module items are assessments carried out to measure the function of an application module. The largest percentage of module items is with Agree responses of $53 \%$ and the smallest percentage with Quite Agree responses of $48 \%$. The three items of multimedia elements are used to measure the convenience of using the application display. The largest percentage of multimedia element items is Agree response of $88 \%$ and the smallest percentage is Quite Agree response of $12 \%$. The fourth aspect of navigation is an assessment of the flow of the application. The largest percentage was in the navigation aspect, with Agree responses of $70 \%$ and the smallest percentage with Quite Agree responses of $28 \%$. Lastly, the usability item is an assessment of the function of the application against adjustments to the company's business processes. The largest percentage of usability items is with Agree responses of $82 \%$ and the smallest percentage with Quite Agree responses of $18 \%$.

\subsubsection{UAT Calculation}

UAT calculation is a measurement made on the Odoo application and also focuses on the sales module by using the Linkerd Summated Rating (LSR) scale measurement to the results of the questionnaire that has been carried out. LSR itself is a scale with measurements based on correspondent attitudes. 
Table 2. Total Responses to the Questionnaire Results for Each Aspect

\begin{tabular}{cc}
\hline Frequency & $\begin{array}{c}\text { Total } \\
\text { Responses }\end{array}$ \\
\hline $\begin{array}{c}\text { Strongly } \\
\text { Dissagree }\end{array}$ & 0 \\
Dissagree & 1 \\
Quaite & 56 \\
Agree & \\
Agree & 159 \\
$\begin{array}{c}\text { Strongly } \\
\text { Agree } \\
\text { Total }\end{array}$ & 4 \\
\hline
\end{tabular}

Table 4. Total Score for Each Correspondent (Score * Total Questions)

\begin{tabular}{cccc}
\hline $\begin{array}{c}\text { Type of } \\
\text { Score }\end{array}$ & Score & $\begin{array}{c}\text { Total } \\
\text { Questions }\end{array}$ & Total \\
\hline Maximum & 5 & 22 & 110 \\
Minimum & 1 & 22 & 22 \\
Medium & 2 & 22 & 44 \\
Quartile I & 3 & 22 & 66 \\
Quartile III & 4 & 22 & 88 \\
\hline
\end{tabular}

Table 3. Total Likert Score of the Questionnaire Results (Total Responses*Score)

\begin{tabular}{ccc}
\hline Frequency & Score & Total \\
\hline $\begin{array}{c}\text { Strongly } \\
\text { Dissagree }\end{array}$ & 1 & 0 \\
Dissagree & 2 & 2 \\
Quaite & 3 & 168 \\
Agree & & 736 \\
Agree & 4 & 20 \\
$\begin{array}{c}\text { Strongly } \\
\text { Agree } \\
\text { Total }\end{array}$ & 5 & 926 \\
\hline
\end{tabular}

Table 5. Total Scores for All Correspondents

(Total Score Responses * Total Respondents)

\begin{tabular}{ccc}
$\begin{array}{c}\text { Type of } \\
\text { Score }\end{array}$ & $\begin{array}{c}\text { Total } \\
\text { Responden }\end{array}$ & Total \\
\hline Maximum & 10 & 1100 \\
Minimum & 10 & 220 \\
Medium & 10 & 440 \\
Quarter I & 10 & 660 \\
Quarter III & 10 & 880
\end{tabular}

\subsubsection{Interpretation of Total Score}

Table 6. Interpretation of Total Score

\begin{tabular}{|c|c|c|c|c|c|c|c|}
\hline \multicolumn{2}{|c|}{ Not successful } & \multicolumn{2}{|c|}{ Less successful } & \multicolumn{2}{|c|}{ Quite successful } & \multicolumn{2}{|c|}{ Positive } \\
\hline Min & Max & Min & Max & Min & Max & Min & Max \\
\hline 220 & 440 & 440 & 660 & 660 & 880 & 880 & 1100 \\
\hline \multicolumn{8}{|c|}{$\begin{array}{l}\text { Total Iscor Responses } \\
\text { Quusestionanare Results }\end{array}$} \\
\hline & & & 440 & 560 & 1100 & & \\
\hline
\end{tabular}

Figure 12. Total Score Respondens Questionnaire Results 
Based on the results of research that has been carried out on the LSR interpretation with a total score of 926 obtained based on 10 respondents is $880<926<1100$ where the interpretation of the total score is considered successful.

\section{Conclusion}

The conclusion obtained is based on the research that has been done, namely the business processes that are currently running in the company are considered inefficient because the system has not been integrated, and therefore reengineering the business process in the sales department is carried out using the Odoo application which has been adjusted to the company's business processes. Reengineering is done, namely adding a bidding process that can be sent via email, checking back on the sales order process and customer invoices that can be sent via email. Based on the results of research using the UAT method and the Linkert scale, it is considered successful with an assessment score of 926. The Odoo application is expected to be able to develop existing features and increase effectiveness by paying attention to bugs that occasionally occur in the application.

\section{References}

[1] S.- Suminten, S. Amelia, and I. D. Sintawati, "Penerapan Enterprise Resourse Planning Penjualan Aksesoris Berbasis Odoo," 2019.

[2] D. Whiteley, An Introduction to Information Systems. 2013.

[3] R. Miclo, M. Lauras, F. Fontanili, J. Lamothe, and S. A. Melnyk, "Demand Driven MRP: assessment of a new approach to materials management," Int. J. Prod. Res., vol. 57, no. 1, pp. 166-181, 2019, doi: 10.1080/00207543.2018.1464230.

[4] A. Ridho and G. Permata Liansari, "Implementasi Sistem Material Requirement Planning (Mrp) Dan E-Commerce Berbasis Enterprise Resource Planning (Erp) Di Pt.Xyz Menggunakan Software Odoo," J. Online Inst. Teknol. Nas., vol. 3, no. 3, pp. 1-14, 2015, [Online].

Available: https://ejurnal.itenas.ac.id/index.php/rekaintegra/article/download/867/1101.

[5] I. D. Made Adi Baskara Joni and I. P. H. Permana, "Pengelolaan Kegiatan Pengabdian Masyarakat dengan Sistem Informasi Manajemen," Lontar Komput. J. IIm. Teknol. Inf., vol. 8, no. 2, p. 124, 2017, doi: 10.24843/lkjiti.2017.v08.i02.p06.

[6] I. D. M. A. B. Joni and I. K. B. Sandika, "Sistem Informasi Manajemen Sebagai Alat Pengelolaan Penelitian Dosen," Lontar Komput. J. IIm. Teknol. Inf., vol. 7, no. 1, p. 51, 2016, doi: 10.24843/lkjiti.2016.v07.i01.p06.

[7] J. T. Informasi, F. Teknik, U. Udayana, B. Jimbaran, H. R. Management, and B. Process, "Pengembangan Sistem Hrm Terintegrasi Dengan Pendekatan Erp," Merpati, vol. 4, no. 3, pp. 259-270, 2016, doi: 10.24843/JIM.

[8] R. Widayanti, "Business Process Reenginering dengan Penerapan Open ERP pada Proses Sales dan Procurement," Ind. Serv., vol. 4 No.1, pp. 8-9, 2018.

[9] S. Mohapatra, Management for Professionals. 2013.

[10] "No Title." https://www.odoo.com/ (accessed Nov. 20, 2020).

[11] T. Hirata, "Customer Satisfaction Planning: The Theory," Cust. Satisf. Plan., pp. 27-42, 2008, doi: 10.1201/b17180-6.

[12] J. Surasma Surung, I. P. Agung Bayupati, and G. Agung Ayu Putri, "The Implementation Of ERP In Supply Chain Management On Conventional Woven Fabric Business," Int. J. Inf. Eng. Electron. Bus., vol. 12, no. 3, pp. 8-18, 2020, doi: 10.5815/ijieeb.2020.03.02.

[13] M. Sales, M. Aplikasi, and V. Odoo, "Reenginering Bisnis Proses Perusahaan Manufaktur," vol. 0.

[14] B. A. Prakosa, "Implementasi dan Konfigurasi Free Open Source Enterprise Resource Planning (ERP) Odoo 9.0 c: Studi Kasus: UD. Morodadi," 2017. 